\title{
1 Road and landscape-context impacts on bird pollination in a 2 Mediterranean-type shrubland of the southeastern Cape Floristic 3 Region
}

$4 \quad$ B. Adriaan Grobler * and Eileen. E. Campbell

5 Botany Department, Nelson Mandela University, Port Elizabeth, Eastern Cape 6000, South

6 Africa

7 * Corresponding author: adriaan.grobler85@gmail.com; Botany Department, PO Box 77000,

8 Nelson Mandela University, Port Elizabeth 6031, South Africa

\section{Abstract}

10 Road verges can provide important habitats for plants, especially in transformed landscapes. However, roads and their associated traffic have several adverse impacts on ecosystems that can disrupt vital ecological processes, including pollination. In transformed landscapes, road effects on pollination might be complemented by impacts of large-scale habitat modification. In these landscapes, road verge populations of plants that rely on pollinators for pollen transfer could thus be at risk of pollination failure. This study investigates the pollination of a reseeding, bird-pollinated shrub, Erica glandulosa, in road verges of a fragmented and transformed rural landscape in the southeastern Cape Floristic Region. We test for road impacts on pollination by comparing number of ruptured anther rings - a proxy for pollination - in fynbos vegetation fragments at different distances from the road (0-10, 20-30 and 40-50 m). We also test whether different land-cover types (intact fynbos, alien thickets and rangelands/pastures) next to road verges influence the number of ruptured anther rings. After controlling for robbing rate and plant density, fewer flowers were pollinated near the road than farther away, and fewer flowers were pollinated where road verges occurred next to alien thickets or pastures/rangelands compared to intact fynbos. However, bird pollination was not excluded in road verges: on average, ca. $20-30 \%$ of flowers were still visited by birds near the road. These findings potentially call into question the suitability of road verges as refugia for seed-dependent, birdpollinated plant species in transformed landscapes.

Keywords: Cape Floristic Region; Erica glandulosa; Fynbos; Landscape transformation; 


\section{1. Introduction}

32 Road verges have been highlighted as important habitats for plants, especially in transformed

33 landscapes where large expanses of natural vegetation have been converted to alternate forms

34 of land use (Arenas et al., 2017; Cale and Hobbs, 1991; Deckers et al., 2004; Leigh and

35 Briggs, 1992; Lewis, 1991; Nicolson, 2010; O’Farrell and Milton, 2006). Although roads and verges can facilitate the spread of alien invasive plants (Ernst, 1998; Gelbard and Belnap, 2003; Hayasaka et al., 2012; Kalwij et al., 2008; Pauchard and Alaback, 2004; Rahlao et al., 2010; Tyser and Worley, 1992), where they are adequately managed, road verges may provide refuge to native plants in landscapes that are otherwise transformed by alien plant invasions. Thus, road verge habitats have become increasingly recognised for their contributions to nature conservation and the maintenance of landscape connectivity (Byrne et al., 2007; Hogbin et al., 1998; Pauwels and Gulinck, 2000; Van Rossum et al., 2004).

Despite these benefits, roads and their associated traffic have several adverse impacts on ecosystems (Coffin, 2007; Forman and Alexander, 1998; Spellerberg, 1998; Trombulak and Frissell, 2000) that can undermine the conservation value of road verge habitats. Roads modify animal behaviour through home range shifts and by altering reproductive success, movement patterns, escape responses, and physiological states (Trombulak and Frissell, 2000). Through this modified behaviour, roads and traffic exert population-level effects by reducing the density or size of animal populations near roads (Fahrig and Rytwinski, 2009; Rytwinski and Fahrig, 2015). In turn, these effects can lead to fragmentation of animal populations (Fahrig et al., 1995; Huijser and Bergers, 2000; Keller and Largiader, 2003), but, more importantly in the context of this study, could also disrupt vital ecological processes facilitated by animals, such as pollination.

Most flowering plant species_ — an estimated 87.5\% (Ollerton et al., 2011)—depend on animals, especially insects, birds, bats, and small mammals, for pollination (Kearns et al., 1998). Road verge populations of plants that rely on pollinators for pollen transfer could thus be at risk of pollination failure, subsequent reproductive failure, and ultimately local extinction (Bond, 1994; Pauw, 2007; Trombulak and Frissell, 2000; Wilcock and Neiland, 2002). Even though certain plants may be able to compensate for insufficient pollination in the short-term, for example through clonal propagation (Pauw and Bond, 2011; Pauw and Hawkins, 2011) or vegetative sprouting (Bond and Midgley, 2001), it is debatable whether 
such mechanisms can facilitate the long-term persistence of species (Bond, 1994), especially considering predicted climate change.

In the fynbos ecosystems of South Africa's Cape Floristic Region (CFR), plant species most at risk of this road-related impact are those that rely on birds for pollination, and whose regeneration depend on seeds. Obligate reseeding plants constitute about half the Cape flora, can be dominant components in fynbos communities, and are well represented in the Ericaceae and Proteaceae (Le Maitre and Midgley, 1992). Ornithophilous members of the Ericaceae and Proteaceae also typically dominate late seral communities in fynbos vegetation (Van Wilgen, 1981). The CFR is comparatively rich in bird-pollinated plants, with roughly $75 \%$ of southern Africa's ornithophilous plant species occurring in the Cape, where they constitute ca. 4\% (around 320 species) of the regional flora (Rebelo, 1987). Pollination by sunbirds (Nectariniidae) in particular is more extensively developed in the CFR than elsewhere in Africa (Manning and Goldblatt, 2012), with more than 44 plant species being exclusively pollinated by a single bird species, the long-billed malachite sunbird (Nectarinia famosa) (Anderson et al., 2005; Geerts and Pauw, 2009). Shorter-billed sunbirds, like the orange-breasted sunbird (Anthobaphes violacea) and southern double-collared sunbird (Cinnyris chalybea), pollinate over 66 species of plants in the Cape (Geerts and Pauw, 2009; Rebelo et al., 1985, 1984), while the cape sugarbird (Promerops cafer, Promeropidae) pollinates at least 20 plant species, typically members of the Proteaceae (Johnson, 2010). This guild of nectarivorous birds thus plays a central role in the reproduction of a significant portion of the Cape flora.

Whereas the direct impacts of roads and traffic on avian populations have received much attention, especially habitat fragmentation and road kill, few studies have investigated the behavioural response of birds to roads (Kociolek et al., 2011; Rytwinski and Fahrig, 2015). Kociolek et al. (2011) found that birds avoid roads due to the physical barrier roads present to movement, and due to artificial light, edge effects, and traffic noise. However, response to roads may be guild- or species-specific (Kuitunen et al., 1998; Laurance et al., 2004; Reijnen et al., 1997, 1996), with certain birds, mostly raptors and scavengers, even being attracted to roads (Dean and Milton, 2003; Morelli et al., 2014). Geerts and Pauw (2011) demonstrated a two-fold decline in pollination rate of an ornithophilous shrub, Erica perspicua, in road verge fynbos of the southwestern Cape, demonstrating the indirect effects of roads on sunbird pollination through changes in bird behaviour. However, the study was conducted along a 
94 minor road that cuts through the Kogelberg Biosphere Reserve where large areas of

95 contiguous fynbos vegetation still occur next to the road. In transformed landscapes, where

96 the conservation value of road verge habitats is potentially highest, road effects on bird

97 behaviour — and thus bird pollination — might be complemented by impacts of large-scale

98 habitat modification.

Much of the land in the CFR has been transformed by agriculture, commercial forestry, urban development, and alien plant invasions. Rouget et al. (2003) found that, collectively, these transforming agents have usurped ca. $30 \%$ of the land in the CFR, and predicted that at least $30 \%$ of the remaining natural vegetation could be transformed by the year 2023 . This largescale change in land cover has led to extensive fragmentation of landscapes in the region.

104 Birds respond to habitat modification and fragmentation in many different ways and, as is the case with roads, the response is often guild- or species-specific (Lindenmayer et al., 2003; Luck and Daily, 2003). Nevertheless, birds in general have been shown to be more sensitive to habitat quality than other factors, including patch size, shape, and location, in fynbos fragments (Dures and Cumming, 2010). Around Cape Town, urbanization reduces the functional diversity of the ecologically important nectarivorous bird guild, with only the short-billed southern double-collared sunbird occurring more than $1 \mathrm{~km}$ into the city (Pauw and Louw, 2012). Armstrong et al. (1996) documented a change in avian community composition from predominantly fynbos species to one dominated by species typical of riparian woodlands after fynbos vegetation had been replaced by pine plantations. They found that specialist nectarivorous sugarbirds were present only infrequently in these artificial forests. Similarly, in Mpumalanga, species diversity of grassland birds was significantly reduced where grasslands were converted to commercial plantations, whereas woodland birds benefited from this change (Allan et al., 1997). Although these studies dealt with plantations, comparable shifts in avian assemblages may be expected where habitats are altered through alien tree invasions (Richardson and Van Wilgen, 2004). Indeed, Dures and

120 Cumming (2010) showed that the presence of invasive Acacia saligna was a significant

121 driver of reduced species richness in avian communities, while Mangachena \& Geerts (2017)

122 found species-depauperate bird assemblages in riparian habitats that were invaded by

123 Eucalyptus camaldunensis. Of particular concern in the latter study was the absence of nectarivores from invaded sites. 
125 Given that both roads and large-scale habitat modification have been demonstrated to have

126 significant impacts on the behaviour of birds, how might these two disturbances combine to

127 affect the pollination of ornithophilous plants in road verges? Here we investigate the

128 pollination of a bird-pollinated shrub, Erica glandulosa, in road verges of a fragmented and

129 highly transformed rural landscape. We test for road impacts on pollination by comparing

130 number of ruptured anther rings (Geerts and Pauw, 2011) of E. glandulosa flowers in fynbos

131 fragments at different distances from the road. Additionally, we test whether the type of land

132 cover next to road verges influence the number of ruptured anther rings of E. glandulosa

133 flowers.

134 2. Methodology

$135 \quad 2.1$ Study area

136 The study took place in the Eastern Cape Province, South Africa, at the southeastern end of

137 the Cape Floristic Region (CFR). We assessed pollination rates of Erica glandulosa along 22

$138 \mathrm{~km}$ of a four-lane divided highway, the N2 national road, between the western outskirts of

139 Port Elizabeth $\left(-33.948^{\circ}, 25.458^{\circ}\right)$ and the Van Stadens area $\left(-33.910^{\circ}, 25.229^{\circ}\right)$. The speed

140 limit along the road is $120 \mathrm{~km} \mathrm{~h}^{-1}$. Fynbos vegetation - a Mediterranean-type shrubland

141 typically dominated by members of the Ericaceae, Proteaceae and Restionaceae - occurs in

142 the road verges, including copious stands of E. glandulosa. Road verge width is consistent

143 throughout at ca. $12-15 \mathrm{~m}$, with the first $2 \mathrm{~m}$ next to the road regularly mowed. The

144 landscape surrounding this stretch of road is rural, but largely transformed and fragmented. It

145 comprises smaller areas of fynbos, pastures and rangelands for dairy and cattle farming, and

146 dense stands of invasive alien trees, especially Acacia mearnsii and A. saligna, but also

147 Eucalyptus and Pinus species. The fynbos fragments along the road range in area from ca.

14825 ha to 350 ha and are all bifurcated by the road. Erica glandulosa populations are restricted

149 to road verges where these abut pastures/rangelands or alien thickets; where road verges

150 border fynbos, E. glandulosa stands can be found at distances more than $100 \mathrm{~m}$ from the

151 road.

\section{$152 \quad 2.2$ Study species}

153 Erica glandulosa Thunb. (Figure $1 \mathrm{a}$ ) is an upright, rounded shrub growing up to $1.5 \mathrm{~m}$ tall

154 (Oliver, 2012; Schumann et al., 1992). Four subspecies are recognised (Oliver and Oliver,

155 2005), with the typical subspecies being the subject of this study (referred to as E. glandulosa 
156

157

158

159

160

161

162

163

164

165

166

167

168

169

170

171

172

173

174

175

176

177

178

179

throughout for the sake of brevity). It occurs on well-drained, acidic sands along the coastal plains and mountains of the southern and southeastern CFR from Mossel Bay to Port Elizabeth, and is a common component of road verge fynbos between Humansdorp and Port Elizabeth (Baker and Oliver, 1967). Flowers are borne in dense, spike-like synflorescenses (Figure $1 \mathrm{~b}$ ) at the branch tips (Oliver and Oliver, 2005; Schumann et al., 1992) and are produced year-round (Oliver, 2012). The corolla is tubular and curved, 18-26 mm long, with a pink to orange colour, or occasionally white (Baker and Oliver, 1967). Plants encountered during this study consistently featured pink flowers as is typical of populations between Humansdorp and Port Elizabeth. Plants do not resprout and rely instead on reproduction from seed to re-establish after disturbance (Hitchcock, 2013). The flowers produce copious amounts of nectar (B.A. Grobler pers. obs., 2016) that, together with their pink colour, attract sunbirds (Hitchcock, 2013). Pollen is deposited onto the beak of the bird as it disturbs the anthers during the process of nectar extraction.
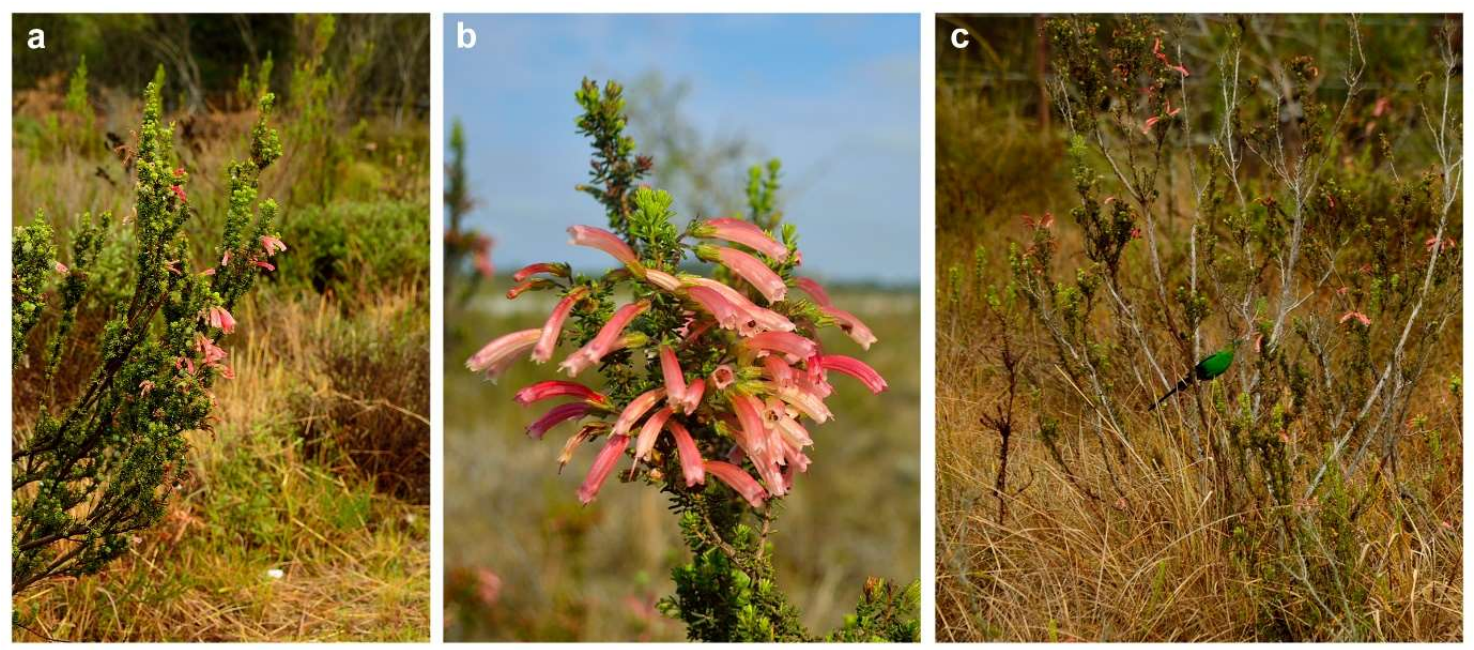

Figure 1. (a) Erica glandulosa growing in road verge fynbos along the N2 national road. (b) The pink, tubular flowers of ornithophilous E. glandulosa arranged in a dense, spike-like synflorescens. (c) A male malachite sunbird (Nectarinia famosa) visiting flowers of E. glandulosa in road verge fynbos.

\subsection{Road impact on pollination}

We used a technique developed by Geerts and Pauw (2011) to determine pollination rates of E. glandulosa. This technique employs anther ring status (intact/ruptured) as a proxy for sunbird visitation and stigma pollen receipt and is an efficient means of assessing pollination rate in ornithophilous Erica species (e.g., Turner et al., 2012). We established $10 \mathrm{~m} \times 10 \mathrm{~m}$ plots within E. glandulosa stands at 0-10 m, 20-30 m and 40-50 m from the road edge (0 m denotes the point at which fynbos vegetation began) at nine sites along the road where fynbos 
occurred in the road verge and on adjacent land (Figure 2 a). Within each plot, five random flowers from each of 16 randomly selected plants were scored for ruptured anther rings and robbing. Wilted flowers were excluded as their anthers could have parted due to the withering process rather than sunbird visitation (Geerts and Pauw, 2011). Cape honeybees (Apis mellifera subsp. capensis) were primarily responsible for nectar robbing, which was indicated by the presence of a small incision towards the base of a flower (Geerts and Pauw, 2011). Plant density of E. glandulosa was also recorded for each plot. While sunbirds are known to preferentially visit pink flowers in colour dimorphic Erica species (Heystek et al., 2014), no white-flowered colour morphs of E. glandulosa were present in any of our plots, and flower colour was not included as a factor. In total, 720 flowers from 144 plants in nine plots were assessed for each distance interval.

\subsection{Land-cover impact on pollination}

We used the same methodology described above to investigate the effect of adjacent land cover on pollination of road verge E. glandulosa populations. For this part of the study, $10 \mathrm{~m} \times 10 \mathrm{~m}$ plots were located in road verge stands of E. glandulosa, starting at the road edge. Plots were positioned adjacent to the three major land-cover types present in the study area, namely fynbos, alien thickets, and pastures/rangelands (Figure 2). Twelve plots (960 flowers from 192 plants) were assessed adjacent to each land-cover type. Fynbos bordering road verges was not always free of alien vegetation, but plots were only located at sites where invasions were relatively sparse and localised, and where the general structure and composition of the vegetation remained intact (Figure 2 a).
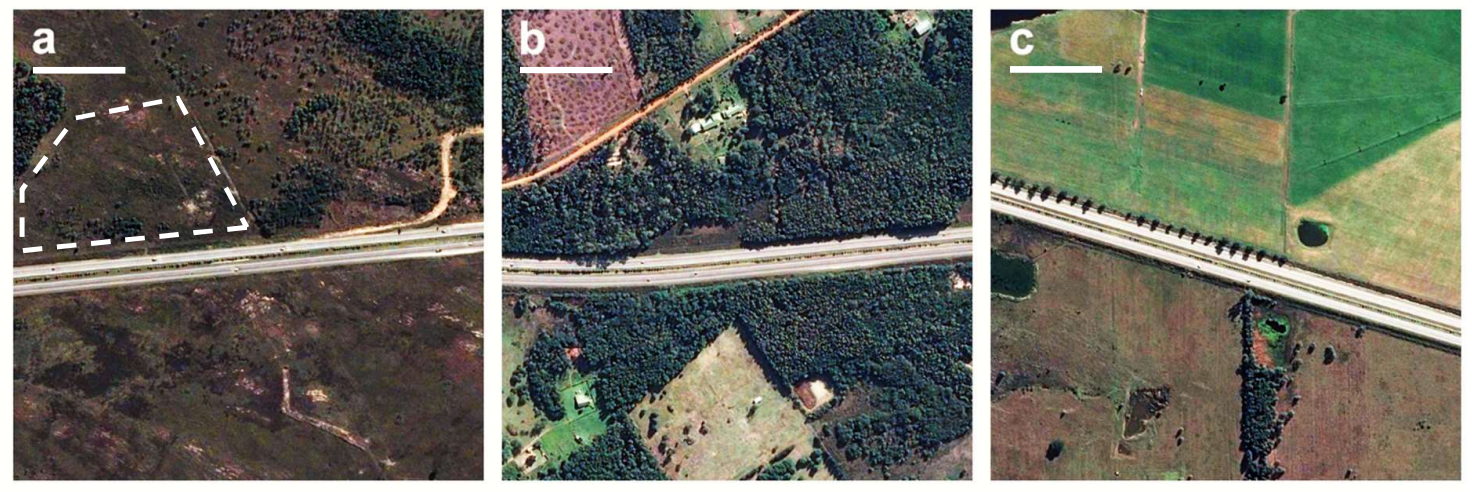

Figure 2. Examples of land-cover types next to road verge populations of Erica glandulosa along the N2 national road: (a) fynbos; (b) alien thickets; and (c) pastures (top) and rangelands (bottom). The highlighted area in (a) shows an example of sparsely invaded fynbos. Scale bars $=100 \mathrm{~m}$. Images: Google, CNES/Astrium. 
205

206

207

208

209

210

211

212

213

214

215

216

217

218

219

220

221

222

223

224

225

226

227

228

229

230

231

232

233

234

235

\subsection{Data analysis}

All data analyses and statistical tests were implemented using R 3.6.1 (R Core Team, 2019). We used generalised linear mixed models (GLMMs), applied with the 'glmer' function in the 'Ime4' R package (Bates et al., 2015), to analyse the response of pollination to road distance and adjacent land cover. These models had a binomial error distribution with a logit link function, and estimated parameters by maximum likelihood (Laplace approximation). Road distance and adjacent land cover were included as fixed effects in their respective models, while nectar robbing and plant density were included as fixed effects in both models. Data for plant density were log-scaled and mean-centred to reduce the effects of extreme values and to negate problems associated with collinearity (Zuur et al., 2009). Random effects were specified in the models to account for autocorrelation inherent in the data due to the nested sampling design. For each model, we used the maximal random effects structure corresponding to the specific nested sampling design (Barr et al., 2013). For the road impact GLMM, random effects were individual plants, plots, and sampling sites, nested in that ascending order, while individual plants nested in plots (plots and sites were synonymous in this sampling protocol) were included as random effects in the land-cover impact GLMM.

Significance tests for all fixed effects in the GLMMs were executed by means of likelihoodratio tests (Type II sums of squares) using the 'mixed' function in the 'afex' R package (Singmann et al., 2017). This method fits the full model and various restricted models in which the parameters corresponding to each of the specified fixed effects are removed. Comparisons between the full model and the restricted models are then used to produce the test statistics. Tukey HSD post-hoc tests with Bonferroni correction for multiple comparisons, implemented via the 'glht' function in the 'multcomp' R package (Hothorn et al., 2008), were used to test for differences in pollination between the three distance plots and between the three land-cover types.

\section{Results}

\subsection{Notes on floral visitors}

Two bird species were seen visiting the flowers of Erica glandulosa, namely the malachite sunbird (Nectarinia famosa) and the southern double-collared sunbird (Cinnyris chalybea). Malachite sunbirds (Figure $1 \mathrm{c}$ ) were the most common visitors and were observed at all fynbos sites and most alien thicket sites (75\%). Southern double-collared sunbirds were 
236 observed at only three fynbos sites (25\%) and three alien thicket sites (25\%). No birds were

237 seen at pasture sites. Cape honeybees (Apis mellifera subsp. capensis) also frequented

238 E. glandulosa flowers and were seen at most sites, although they were most abundant in road 239 verges next to alien thickets.

\section{$240 \quad 3.2$ Road impact on pollination}

241 Road distance had an effect on bird pollination (Table 1; GLMM likelihood-ratio test, $\chi^{2}=$ $24262.76, P<0.001$ ), with lower pollination rates next to the road than farther away from the 243 road (Figure 3; Tukey HSD post hoc, $P<0.001$ ). Pollination rates were marginally higher at 244 40-50 m compared to 20-30 m (Tukey HSD post hoc, $P=0.10$ ). On average, pollination of

245 E. glandulosa within $10 \mathrm{~m}$ of the road declined by $35 \%$ compared to pollination of plants at $24620-30 \mathrm{~m}$ from the road, and by $41 \%$ compared to plants at $40-50 \mathrm{~m}$ from the road (Figure 3 ).

247 Flower robbing rate and E. glandulosa plant density varied between plots at different

248 distances from the road (Table 2). However, we found no evidence of these two factors

249 affecting pollination (Table 1).

\section{$250 \quad 3.3$ Adjacent land-cover impact on pollination}

251 The type of land cover next to road verges impacted on bird pollination (Table 1; GLMM

252 likelihood-ratio test, $\chi^{2}=8.03, P=0.02$ ), with higher pollination rates adjacent to fynbos than

253 next to either alien thickets or pastures/rangelands (Figure 4; Tukey HSD post hoc, $P<0.05$ ).

254 In comparison with those next to fynbos, road verge populations of E. glandulosa abutting

255 alien thickets exhibited an average decline of $24 \%$ in pollination rate, while average

256 pollination rate in populations adjacent to pastures/rangelands were $32 \%$ lower compared to

257 those bordering fynbos (Figure 4). We found no evidence of pollination rates differing

258 between road verge E. glandulosa next to alien thickets and pastures/rangelands. Flower

259 robbing rate and E. glandulosa plant density varied between plots adjacent to different land-

260 cover types (Table 2), but we could not detect an impact of these factors on pollination

261 (Table 1). 
263 Table 1: Significance tests for the effects of road distance, adjacent land cover, nectar robbing, and plant density on percentage of disturbed anther rings (pollination rate) in Erica glandulosa by means of generalised linear mixed models likelihood-ratio tests.

\begin{tabular}{llll}
\hline & d.f. & $\chi^{2}$ & $P$ \\
\hline Road impact model: & & & \\
Road distance * & 2 & 62.76 & $<0.001$ \\
Nectar robbing & 1 & 0.49 & 0.48 \\
Plant density $\dagger$ & 1 & 0.88 & 0.35 \\
Land-cover impact model: & & & \\
Adjacent land cover * & 2 & 8.03 & 0.02 \\
Nectar robbing & 1 & 0.66 & 0.42 \\
Plant density $\dagger$ & 1 & 0.14 & 0.71 \\
\hline * Significant effect at $\alpha=0.05$ & & & \\
$\dagger$ Log-scaled and mean-centred & & &
\end{tabular}

267 Table 2: Summary of Erica glandulosa flower robbing rate and plant density at different distances from the road and next to different land-cover types.

\begin{tabular}{lll}
\hline & $\begin{array}{l}\text { Mean robbing rate }(\%) \\
\pm \mathrm{SE}(n \text { flowers })\end{array}$ & $\begin{array}{l}\text { Mean plant density }\left(\mathrm{m}^{-2}\right) \pm \\
\text { SE }(n \text { plots })\end{array}$ \\
\hline $\begin{array}{l}\text { Road distance: } \\
0-10 \mathrm{~m}\end{array}$ & $10.14 \pm 4.42(720)$ & $0.97 \pm 0.14(9)$ \\
$20-30 \mathrm{~m}$ & $12.08 \pm 5.19(720)$ & $0.67 \pm 0.11(9)$ \\
$40-50 \mathrm{~m}$ & $15.14 \pm 5.02(720)$ & $0.44 \pm 0.07(9)$ \\
Adjacent land cover: & & \\
Fynbos & $9.06 \pm 3.32(960)$ & $1.05 \pm 0.16(12)$ \\
Alien thicket & $21.88 \pm 5.20(960)$ & $0.60 \pm 0.05(12)$ \\
Pasture/rangeland & $12.19 \pm 2.09(960)$ & $0.45 \pm 0.06(12)$ \\
\hline
\end{tabular}




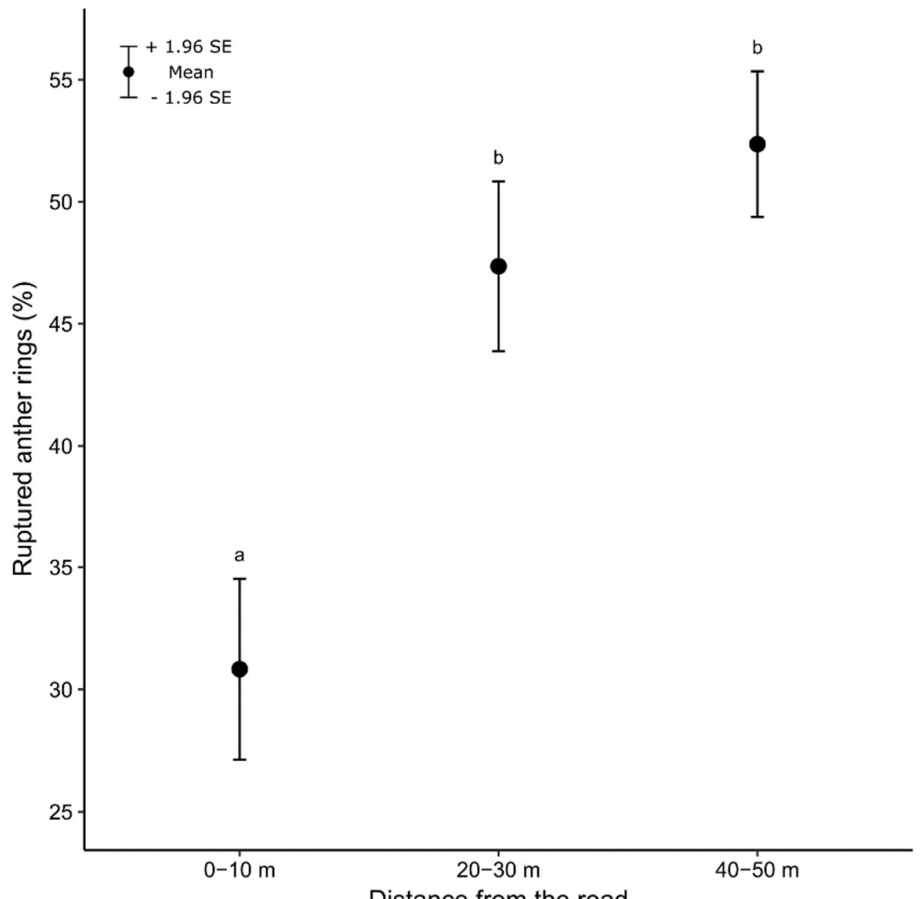

Figure 3: Distance from the road had a significant effect on the pollination rate of ornithophilous Erica glandulosa (GLMM likelihood-ratio test, $\chi^{2}=62.76, P<0.001$ ). Error bars indicate $\pm 95 \%$ confidence intervals. Different letters above bars indicate a significant difference between means (Tukey HSD post hoc, $P<0.001$ ).

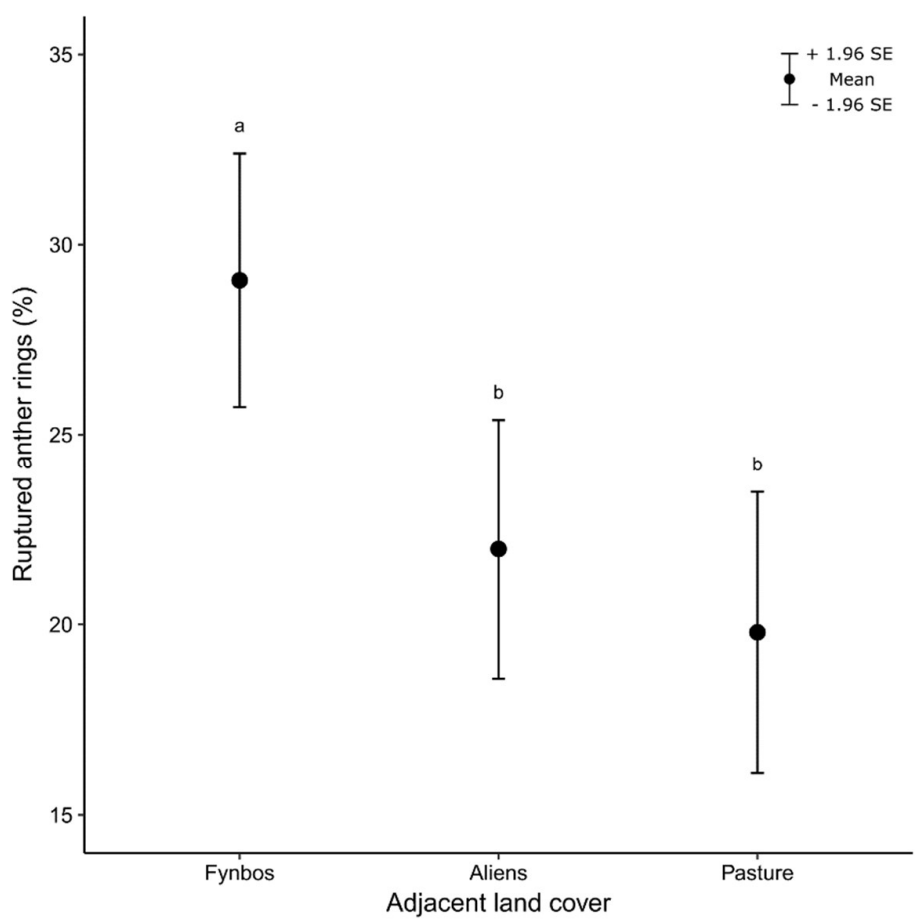

Figure 4: Adjacent land cover has a significant effect on the pollination of ornithophilous Erica glandulosa in road verge fynbos (GLMM likelihood-ratio test, $\chi^{2}=8.03, P=0.02$ ). Error bars indicate $\pm 95 \%$ confidence intervals. Different letters above bars indicate a significant difference between means (Tukey HSD post hoc, $P<0.05)$. 


\section{4. Discussion}

\section{$280 \quad 4.1$ Road impact on bird pollination}

281 The results of this study indicate that a road impacts negatively on bird pollination in fynbos

282 fragments of a transformed rural landscape in the southeastern CFR. On average, pollination of E. glandulosa within $30 \mathrm{~m}$ of the road declined by ca. 35-40\% compared to plants farther away. These findings are consistent with those of Geerts and Pauw (2011), who showed that a two-lane tar road in the southwestern CFR caused a two-fold decline in pollination of ornithophilous Erica perspicua near the road. In comparison to the road investigated in the current study (a highway), the one investigated by Geerts and Pauw (2011) (a regional road) is smaller and carries less traffic at lower speeds. The impact of this regional road on pollination was evident up to $10 \mathrm{~m}$ away, but larger, busier roads are expected to have greater impacts on bird behaviour reaching farther from the road (Forman et al., 2002; Reijnen et al., 1996; Van der Zande et al., 1980). Although the evidence is not very strong, the results of our study support this notion as pollination rates were marginally higher at 40-50 $\mathrm{m}$ from the road compared to 20-30 m (Figure 3), suggesting that birds visit flowers beyond $30 \mathrm{~m}$ from the road more often. Nevertheless, the road impact on bird pollination remains most significant within $10 \mathrm{~m}$ of the road, after which it appears to diminish.

While we did not explicitly investigate the cause of reduced bird pollination nearer the road, disturbance of birds by traffic is the most likely reason. In their review of road effects on avian populations, Kociolek et al. (2011) identified traffic noise as the most significant indirect road impact that prompts road avoidance in birds. Through an experiment where synthetic traffic noise was applied to a roadless area, McClure et al. (2013) showed that, in the absence of other confounding road effects (e.g. chemical pollution, roadkill, and visual disturbance), traffic noise could reduce bird abundance by over a quarter, and elicited an almost complete avoidance in certain species. Traffic noise makes it difficult for birds to detect song by conspecifics, which in turn hinders the attraction of mates (Pohlman et al., 2009; Rheindt, 2003), the establishment and maintenance of territories (Habib et al., 2006; Mockford and Marshall, 2009), the detection of predators (Francis et al., 2009; Slabbekoorn and Ripmeester, 2008), and general communication with flock members or offspring

308 (Leonard and Horn, 2005; Lohr et al., 2003). Higher levels of traffic have been linked to 309 lower population densities near roads in several bird species, with average traffic densities above 30,000 vehicles per day affecting up to $55 \%$ of species in an area (Reijnen and Foppen, 
311 2006). In the Netherlands, for a road with an average traffic density of 50,000 vehicles per

312 day, this effect is estimated to reach up to $365 \mathrm{~m}$ from the road in woodlands, and up to

$313560 \mathrm{~m}$ in grasslands (Reijnen and Foppen, 2006). In the United States, this effect on grassland

314 birds along a highway carrying more than 30,000 vehicles per day was estimated at 1,200 m

315 (Forman et al., 2002). In comparison to these effect-distances, the 10-30 m effect distance on

316 bird pollination revealed in our study is relatively minor.

\section{$317 \quad 4.2$ Impact of landscape context on bird pollination}

318 Bird pollination in road verges is not only affected by road disturbance; the type of land cover

319 that occurs next to the verge also impacts on pollination (Table 1), with plants in verges

320 neighbouring transformed land experiencing a significant reduction in pollination (Figure 4).

321 Since McIntyre and Hobbs (1999) proposed their conceptual model of habitat fragmentation,

322 several studies, including those investigating avian communities (Lindenmayer et al., 2003;

323 Palmer et al., 2008; Zurita and Bellocq, 2012), have shown that a simple binary classification

324 of habitat versus non-habitat is inappropriate for interpreting the response of organisms to

325 habitat fragmentation and modification. Rather, viewing habitat modification as a continuum

326 or gradient allows for a more suitable interpretation of habitat use in transformed landscapes.

327 Based on this premise, it is improbable that modified habitats, such as the alien thickets and

328 pastures/rangelands considered in the current study, will entirely exclude birds and so act as

329 an impervious barrier to prevent them from accessing resources that occur in adjacent road

330 verges. For example, a study by Forman et al. (2002) revealed no significant effect of

331 adjacent land use (expressed as percent built area) on the presence or breeding behaviour of

332 birds in habitat fragments along roads, although road disturbance (distance from the road) did

333 have a significant impact. For this same reason, it is also unreasonable to expect a complete

334 elimination of ornithophily in road verges abutting transformed land: as the results of our

335 study show, on average, ca. $20 \%$ of E. glandulosa flowers in verges neighbouring

336 transformed land are still visited by sunbirds (Figure 4).

337 Although habitat modification did not preclude sunbird visitation in road verges, it did reduce

338 the number of flowers that were pollinated. Compared to those bordering fynbos,

339 E. glandulosa abutting alien thickets and pastures/rangelands exhibited an average decline of

$340 \quad 24-32 \%$ in pollination rate. In the southwestern CFR, invasive Acacia thickets support a large

341 subset of the regional avifauna (Rogers and Chown, 2014). The bird communities in these

342 thickets have densities and species richness comparable to those found in some natural sites, 
343 but, importantly, they typically lack nectarivores. Similarly, the replacement of indigenous

344 fynbos vegetation by pines (Armstrong et al., 1996) and eucalypts (Mangachena and Geerts,

345 2017) also results in the displacement of nectarivores. Increased landscape heterogeneity (i.e.,

346 habitat transformation) is associated with reduced species richness and diversity of

347 nectarivorous birds in southern Mexico (Pineda-Diez de Bonilla et al., 2012), while this same

348 guild prefers natural forest habitats to pastures and plantations in transformed landscapes of

349 southeastern Australia (Hsu et al., 2010). In Belize, the expansion of maintained pastures

350 have led to a significant reduction in species richness of bird communities, and the absence of

351 nectar-feeding birds is conspicuous in these depauperate assemblages (Saab and Petit, 1992).

352 The development of a golf estate in the southwestern Cape, which largely replaced fynbos

353 habitats with built-up areas and golf greens similar in composition and structure to

354 maintained pastures, likewise resulted in reduced abundance of nectarivores (Fox and

355 Hockey, 2007). This bird guild thus appears to be particularly sensitive to habitat

356 modification, including the transformation of natural habitat to land-cover types so prevalent

357 in the landscape surrounding road verges investigated in our study, as well as elsewhere in

358 the CFR. The conversion of fynbos to alien thickets and pastures/rangelands drastically alters

359 the composition and structure of the vegetation and reduces the diversity of native plants

360 (Holmes and Cowling, 1997; Le Roux, 1988; Richardson et al., 1989). This causes a

361 reduction in food resources — in terms of both abundance and diversity — which has been

362 linked to lower abundances of specialist nectar-feeding birds (Blake and Loiselle, 2001;

363 Chalmandrier et al., 2013; Driscoll, 1977; Geerts et al., 2011; Gray et al., 2007). It seems

364 likely then that lower abundances of nectarivorous birds in these modified habitats is the most

365 probable cause of reduced pollination of E. glandulosa in verges next to transformed land.

366 However, this hypothesis remains to be tested.

\section{5. Conclusion}

368 The results of this study have demonstrated the impacts of road disturbance and landscape

369 context on the pollination of ornithophilous road verge plants. To determine whether such a

370 disrupted mutualism has important ecological implications for specific plant species, it is

371 important to consider whether seed set is pollen limited, and whether population growth is

372 seed limited (Anderson et al., 2011; Pauw and Bond, 2011). However, declines in pollination

373 and subsequent pollen limitation have been shown to be the most proximate cause of reduced

374 reproductive success - in terms of lower fruit- or seed-set-in plant populations in 
375 fragmented landscapes (Aguilar et al., 2006). Thus, even though reproductive output was not

376 quantified in the current study, the demonstrated reduction in pollination of road verge plant

377 populations is expected to have a negative effect on the fecundity of plants in verges. This

378 potentially calls into question the suitability of road verges as refugia for bird-pollinated plant

379 species in transformed landscapes. However, our results also indicate that pollination by birds

380 is not excluded in these settings: on average, birds still visited ca. $20-30 \%$ of road verge

381 plants. Whether this rate of pollination is sufficient to sustain populations of bird-pollinated,

382 seed-dependent road verge plants remains to be tested.

\section{Competing Interests}

384 The authors declare that they have no competing interests.

\section{Author Contributions}

BAG designed the study, collected the data, analysed the data, prepared the figures and tables, authored drafts of the manuscript and approved the final draft. EEC reviewed drafts of the manuscript and approved the final draft.

\section{Acknowledgments}

The South African National Research Foundation (NRF) and the South African National Roads Authority (SANRAL) is thanked for financial support. Roland Thompson from SANRAL is thanked for permission to access land under his management. We are grateful to Shandon Carvalho for his assistance in the field.

\section{References}

Aguilar, R., Ashworth, L., Galetto, L., Aizen, M.A., 2006. Plant reproductive susceptibility to habitat fragmentation: Review and synthesis through a meta-analysis. Ecology Letters 9, 968-980.

Allan, D.G., Harrison, J.A., Navarro, R., van Wilgen, B.W., Thompson, M.W., 1997. The impact of commercial afforestation on bird populations in Mpumalanga Province, South Africa-Insights from bird-atlas data. Biological Conservation 79, 173-185.

Anderson, B., Cole, W.W., Barrett, S.C.H., 2005. Specialized bird perch aids crosspollination. Nature 435, 41-42.

Anderson, S.H., Kelly, D., Ladley, J.J., Molloy, S., Terry, J., 2011. Cascading effects of bird 

functional extinction reduce pollination and plant density. Science 331, 1068-1071.

Arenas, J.M., Escudero, A., Mola, I., Casado, M.A., 2017. Roadsides: An opportunity for biodiversity conservation. Applied Vegetation Science 38, 42-49.

Armstrong, A.J., Van Hensbergen, H.J., Scott, D.F., Milton, S.J., 1996. Are pine plantations "inhospitable seas" around remnant native habitat within south-western Cape forestry areas? South African Forestry Journal 176, 1-9.

Baker, H.A., Oliver, E.G.H., 1967. Ericas in Southern Africa. Purnell, Cape Town.

Barr, D.J., Levy, R., Scheepers, C., Tily, H.J., 2013. Random effects structure for confirmatory hypothesis testing: Keep it maximal. Journal of Memory and Language 68, $255-278$.

Bates, D., Maechler, M., Bolker, B., Walker, S., 2015. Fitting linear mixed-effects models using lme4. Journal of Statistical Software 67, 1-48.

Blake, J.G., Loiselle, B.A., 2001. Bird assemblages in second-growth and old-growth forests, Costa Rica: Perspectives from mist nets and point counts. The Auk 118, 304-326.

Bond, W.J., 1994. Do mutualisms matter? Assessing the impact of pollinator and disperser disruption on plant extinction. Philosophical Transactions of the Royal Society B: Biological Sciences 344, 83-90.

Bond, W.J., Midgley, J.J., 2001. Ecology of sprouting in woody plants: The persistence niche. Trends in Ecology and Evolution 16, 45-51.

Byrne, M., Elliott, C.P., Yates, C., Coates, D.J., 2007. Extensive pollen dispersal in a birdpollinated shrub, Calothamnus quadrifidus, in a fragmented landscape. Molecular Ecology 16, 1303-1314.

Cale, P., Hobbs, R.J., 1991. Condition of roadside vegetation in relation to nutrient status, in: Saunders, D.A., Hobbs, R.J. (Eds.), Nature Conservation 2: The Role of Corridors. Surrey Beatty \& Sons, Chipping Norton, pp. 353-362.

Chalmandrier, L., Midgley, G.F., Barnard, P., Sirami, C., 2013. Effects of time since fire on birds in a plant diversity hotspot. Acta Oecologica 49, 99-106.

Coffin, A.W., 2007. From roadkill to road ecology: A review of the ecological effects of roads. Journal of Transport Geography 15, 396-406.

Dean, W., Milton, S., 2003. The importance of roads and road verges for raptors and crows in the Succulent and Nama-Karoo, South Africa. Ostrich: Journal of African Ornithology 74, 181-186.

Deckers, B., Becker, P. De, Honnay, O., Hermy, M., Muys, B., 2004. Sunken roads as habitats for forest plant species in a dynamic agricultural landscape: Effects of age and isolation. Journal of Biogeography 32, 99-109.

Driscoll, P., 1977. Comparison of bird counts from pine forest and indigenous vegetation. Australian Wildlife Research 4, 281.

Dures, S.G., Cumming, G.S., 2010. The confounding influence of homogenising invasive species in a globally endangered and largely urban biome: Does habitat quality dominate avian biodiversity? Biological Conservation 143, 768-777.

Ernst, W.H.O., 1998. Invasion, dispersal and ecology of the South African neophyte Senecio inaequidens in The Netherlands: From wool alien to railway and road alien. Acta Botanica Neerlandica 47, 131-151. 
Fahrig, L., Pedlar, J.H., Pope, S.E., Taylor, P.D., Wegner, J.F., 1995. Effect of road traffic on amphibian density. Biological Conservation 73, 177-182.

Fahrig, L., Rytwinski, T., 2009. Effects of roads on animal abundance: An empirical review and synthesis. Ecology \& Society 14, 1-20.

Forman, R.T.T., Alexander, L.E., 1998. Roads and their major ecological effects. Annual Review of Ecology, Evolution, and Systematics 29, 207-231.

Forman, R.T.T., Reineking, B., Hersperger, A.M., 2002. Road traffic and nearby grassland bird patterns in a suburbanizing landscape. Environmental Management 29, 782-800.

Fox, S.J.C., Hockey, P.A.R., 2007. Impacts of a South African coastal golf estate on shrubland bird communities. South African Journal of Science 103, 27-34.

Francis, C.D., Ortega, C.P., Cruz, A., 2009. Noise pollution changes avian communities and species interactions. Current Biology 19, 1415-1419.

Geerts, S., Malherbe, S.D.T., Pauw, A., 2011. Reduced flower visitation by nectar-feeding birds in response to fire in Cape fynbos vegetation, South Africa. Journal of Ornithology $153,297-301$.

Geerts, S., Pauw, A., 2009. Hyper-specialization for long-billed bird pollination in a guild of South African plants: The malachite sunbird pollination syndrome. South African Journal of Botany 75, 699-706.

Geerts, S., Pauw, A., 2011. Easy technique for assessing pollination rates in the genus Erica reveals road impact on bird pollination in the Cape fynbos, South Africa. Austral Ecology 36, 656-662.

Gelbard, J.L., Belnap, J., 2003. Roads as conduits for exotic plant invasions in a semiarid landscape. Conservation Biology 17, 420-432.

Gray, M.A., Baldauf, S.L., Mayhew, P.J., Hill, J.K., 2007. The response of avian feeding guilds to tropical forest disturbance. Conservation Biology 21, 133-141.

Habib, L., Bayne, E.M., Boutin, S., 2006. Chronic industrial noise affects pairing success and age structure of ovenbirds Seiurus aurocapilla. Journal of Applied Ecology 44, 176184.

Hayasaka, D., Akasaka, M., Miyauchi, D., Box, E.O., Uchida, T., 2012. Qualitative variation in roadside weed vegetation along an urban-rural road gradient. Flora 207, 126-132.

Heystek, A., Geerts, S., Barnard, P., Pauw, A., 2014. Pink flower preference in sunbirds does not translate into plant fitness differences in a polymorphic Erica species. Evolutionary Ecology 28, 457-470.

Hitchcock, A., 2013. Erica glandulosa subsp. glandulosa Thunb. [WWW Document]. PlantZAfrica. URL http://pza.sanbi.org/erica-glandulosa-subsp-glandulosa (accessed 9.2.16).

Hogbin, P.M., Ayre, D.J., Whelan, R.J., 1998. Genetic variation and reproductive success of road verge populations of the rare shrub Grevillea barklyana (Proteaceae). Heredity 80, $180-186$.

Holmes, P.M., Cowling, R.M., 1997. The effects of invasion by Acacia saligna on the guild structure and regeneration capabilities of South African fynbos shrublands. Journal of Applied Ecology 34, 317-332.

Hothorn, T., Bretz, F., Westfall, P., 2008. Simultaneous inference in general parametric 
models. Biometrical Journal 50, 346-363.

Hsu, T., French, K., Major, R., 2010. Avian assemblages in eucalypt forests, plantations and pastures in northern NSW, Australia. Forest Ecology and Management 260, 1036-1046.

Huijser, M.P., Bergers, P.J.M., 2000. The effect of roads and traffic on hedgehog (Erinaceus europaeus) populations. Biological Conservation 95, 111-116.

Johnson, S.D., 2010. The pollination niche and its role in the diversification and maintenance of the southern African flora. Philosophical Transactions of the Royal Society B: Biological Sciences 365, 499-516.

Kalwij, J.M., Milton, S.J., McGeoch, M.A., 2008. Road verges as invasion corridors? A spatial hierarchical test in an arid ecosystem. Landscape Ecology 23, 439-451.

Kearns, C.A., Inouye, D.W., Waser, N.M., 1998. Endangered mutualisms: The conservation of plant-pollinator interactions. Annual Review of Ecology and Systematics 29, 83-112.

Keller, I., Largiader, C.R., 2003. Recent habitat fragmentation caused by major roads leads to reduction of gene flow and loss of genetic variability in ground beetles. Proceedings of the Royal Society B: Biological Sciences 270, 417-423.

Kociolek, A. V, Clevenger, A.P., St. Clair, C.C., Proppe, D.S., 2011. Effects of road networks on bird populations. Conservation Biology 25, 241-249.

Kuitunen, M., Rossi, E., Stenroos, A., 1998. Do highways influence density of land birds? Environmental Management 22, 297-302.

Laurance, S.G.W., Stouffer, P.C., Laurance, W.F., 2004. Effects of road clearings on movement patterns of understory rainforest birds in Central Amazonia. Conservation Biology 18, 1099-1109.

Le Maitre, D.C., Midgley, J.J., 1992. Plant reproductive ecology, in: Cowling, R.M. (Ed.), The Ecology of Fynbos: Nutrients, Fire and Diversity. Oxford University Press, Cape Town, pp. 135-74.

Le Roux, G.H., 1988. Die gebruik van die Kaapse fynbos vir weiding en die probleme wat dit skep. South African Forestry Journal 146, 51-54.

Leigh, J.H., Briggs, J.D. (Eds.), 1992. Threatened Australian Plants: Overview and Case Studies. Australian National Parks and Wildlife Service, Canberra.

Leonard, M.L., Horn, A.G., 2005. Ambient noise and the design of begging signals. Proceedings of the Royal Society B: Biological Sciences 272, 651-656.

Lewis, S.A., 1991. The conservation and management of roadside vegetation in South Australia, in: Saunders, D.A., Hobbs, R.J. (Eds.), Nature Conservation 2: The Role of Corridors. Surrey Beatty \& Sons, Chipping Norton, pp. 313-318.

Lindenmayer, D.B., McIntyre, S., Fischer, J., 2003. Birds in eucalypt and pine forests: Landscape alteration and its implications for research models of faunal habitat use. Biological Conservation 110, 45-53.

Lohr, B., Wright, T.F., Dooling, R.J., 2003. Detection and discrimination of natural calls in masking noise by birds: Estimating the active space of a signal. Animal Behaviour 65, 763-777.

Luck, G.W., Daily, G.C., 2003. Tropical countryside bird assemblages: Richness, composition, and foraging differ by landscape context. Ecological Applications 13, 235247. 
Mangachena, J.R., Geerts, S., 2017. Invasive alien trees reduce bird species richness and abundance of mutualistic frugivores and nectarivores; a bird's eye view on a conflict of interest species in riparian habitats. Ecological Research 1-10.

Manning, J.C., Goldblatt, P., 2012. Plants of the Greater Cape Floristic Region 1: The Core Cape Flora, Strelitzia 29. South African National Biodiversity Institute, Pretoria.

McClure, C.J.W., Ware, H.E., Carlisle, J., Kaltenecker, G., Barber, J.R., 2013. An experimental investigation into the effects of traffic noise on distributions of birds: Avoiding the phantom road. Proceedings of the Royal Society: Biological Sciences 280, 20132290.

McIntyre, S., Hobbs, R., 1999. A framework for conceptualizing human effects on landscapes and its relevance to management and research models. Conservation Biology $13,1282-1292$.

Mockford, E.J., Marshall, R.C., 2009. Effects of urban noise on song and response behaviour in great tits. Proceedings of the Royal Society B: Biological Sciences 276, 2979-2985.

Morelli, F., Beim, M., Jerzak, L., Jones, D., Tryjanowski, P., 2014. Can roads, railways and related structures have positive effects on birds? - A review. Transportation Research Part D: Transport and Environment 30, 21-31.

Nicolson, G., 2010. Road reserves as conservation assets: Exploring the species of conservation concern and the ecological condition of the N7 road reserve. University of Cape Town.

O'Farrell, P.J., Milton, S.J., 2006. Road verge and rangeland plant communities in the southern Karoo: Exploring what influences diversity, dominance and cover. Biodiversity and Conservation 15, 921-938.

Oliver, E.G.H., 2012. Ericaceae, in: Manning, J., Goldblatt, P. (Eds.), Plants of the Greater Cape Floristic Region 1: The Core Cape Flora. South African National Biodiversity Institute, Pretoria.

Oliver, E.G.H., Oliver, I.M., 2005. The genus Erica (Ericaceae) in southern Africa: taxonomic notes 2. Bothalia 35, 121-148.

Ollerton, J., Winfree, R., Tarrant, S., 2011. How many flowering plants are pollinated by animals? Oikos 120, 321-326.

Palmer, G.C., Fitzsimons, J.A., Antos, M.J., White, J.G., 2008. Determinants of native avian richness in suburban remnant vegetation: Implications for conservation planning. Biological Conservation 141, 2329-2341.

Pauchard, A., Alaback, P.B., 2004. Influence of elevation, land use, and landscape context on patterns of alien plant invasions along roadsides in protected areas of south-central Chile. Conservation Biology 18, 238-248.

Pauw, A., 2007. Collapse of a pollination web in small conservation areas. Ecology 88, 1759-1769.

Pauw, A., Bond, W.J., 2011. Mutualisms matter: Pollination rate limits the distribution of oilsecreting orchids. Oikos 120, 1531-1538.

Pauw, A., Hawkins, J.A., 2011. Reconstruction of historical pollination rates reveals linked declines of pollinators and plants. Oikos 120, 344-349.

Pauw, A., Louw, K., 2012. Urbanization drives a reduction in functional diversity in a guild 
of nectar-feeding birds. Ecology and Society 17, art27.

Pauwels, F., Gulinck, H., 2000. Changing minor rural road networks in relation to landscape sustainability and farming practices in West Europe. Agriculture, Ecosystems \& Environment 77, 95-99.

Pineda-Diez de Bonilla, E., León-Cortés, J.L., Rangel-Salazar, J.L., 2012. Diversity of bird feeding guilds in relation to habitat heterogeneity and land-use cover in a humanmodified landscape in southern Mexico. Journal of Tropical Ecology 28, 369-376.

Pohlman, C.L., Turton, S.M., Goosem, M., 2009. Temporal variation in microclimatic edge effects near powerlines, highways and streams in Australian tropical rainforest. Agricultural and Forest Meteorology 149, 84-95.

R Core Team, 2019. R: A language and environment for statistical computing.

Rahlao, S.J., Milton, S.J., Esler, K.J., Barnard, P., 2010. The distribution of invasive Pennisetum setaceum along roadsides in western South Africa: The role of corridor interchanges. Weed Research 50, 537-543.

Rebelo, A.G., 1987. Bird pollination in the Cape Flora, in: Rebelo, A.G. (Ed.), A Preliminary Synthesis of Pollination Biology in the Cape Flora. National Scientific Programs Unit: Council for Scientific and Industrial Research, Pretoria, pp. 83-108.

Rebelo, A.G., Siegfried, W.R., Crowe, A.A., 1984. Avian pollinators and the pollination syndromes of selected mountain fynbos plants. South African Journal of Botany 3, 285296.

Rebelo, A.G., Siegfried, W.R., Oliver, E.G.H., 1985. Pollination syndromes of Erica species in the south-western Cape. South African Journal of Botany 51, 270-280.

Reijnen, R., Foppen, R., 2006. Impact of road traffic on breeding bird populations, in: Davenport, J., Davenport, J.L. (Eds.), The Ecology of Transportation: Managing Mobility for the Environment. Springer, Dordrecht, pp. 255-274.

Reijnen, R., Foppen, R., Meeuwsen, H., 1996. The effects of traffic on the density of breeding birds in Dutch agricultural grasslands. Biological Conservation 75, 255-260.

Reijnen, R., Foppen, R., Veenbaas, G., 1997. Disturbance by traffic of breeding birds: Evaluation of the effect and considerations in planning and managing road corridors. Biodiversity and Conservation 6, 567-581.

Rheindt, F.E., 2003. The impact of roads on birds: Does song frequency play a role in determining susceptibility to noise pollution? Journal für Ornithologie 144, 295-306.

Richardson, D.M., Macdonald, I.A.W., Forsyth, G.G., 1989. Reductions in plant species richness under stands of alien trees and shrubs in the fynbos Biome. South African Forestry Journal 149, 1-8.

Richardson, D.M., Van Wilgen, B.W., 2004. Invasive alien plants in South Africa: How well do we understand the ecological impacts? South African Journal of Science 100, 45-52.

Rogers, A.M., Chown, S.L., 2014. Novel ecosystems support substantial avian assemblages: The case of invasive alien Acacia thickets. Diversity and Distributions 20, 34-45.

Rouget, M., Richardson, D.M., Cowling, R.M., Lloyd, J.W., Lombard, A.T., 2003. Current patterns of habitat transformation and future threats to biodiversity in terrestrial ecosystems of the Cape Floristic Region, South Africa. Biological Conservation 112, 63-85. 
Rytwinski, T., Fahrig, L., 2015. The impacts of roads and traffic on terrestrial animal populations, in: Van Der Ree, R., Smith, D.J., Grilo, C. (Eds.), Handbook of Road Ecology. Wiley Blackwell, Chichester, pp. 237-246.

Saab, V.A., Petit, D.R., 1992. Impact of pasture development on winter bird communities in Belize, Central America. The Condor 94, 66-71.

Schumann, D., Kirsten, G., Oliver, E.G.H., 1992. Ericas of South Africa. Fernwood Press, Cape Town.

Singmann, H., Bolker, B., Westfall, J., Aust, F., 2017. afex: Analysis of Factorial Experiments.

Slabbekoorn, H., Ripmeester, A.E.P., 2008. Birdsong and anthropogenic noise: Implications and applications for conservation. Molecular Ecology 17, 72-83.

Spellerberg, I.F., 1998. Ecological effects of roads and traffic: A literature review. Global Ecology and Biogeography Letters 7, 317-333.

Trombulak, S.C., Frissell, C.A., 2000. Review of ecological effects of roads on terrestrial and aquatic communities. Conservation Biology 14, 18-30.

Turner, R.C., Midgley, J.J., Barnard, P., Simmons, R.E., Johnson, S.D., 2012. Experimental evidence for bird pollination and corolla damage by ants in the short-tubed flowers of Erica halicacaba (Ericaceae). South African Journal of Botany 79, 25-31.

Tyser, R.W., Worley, C.A., 1992. Alien Flora in Grasslands Adjacent to Road and Trail Corridors in Glacier National Park, Montana (U.S.A.). Conservation Biology 6, 253262.

Van der Zande, A.N., Ter Keurs, W.J., Van der Weijden, W.J., 1980. The impact of roads on the densities of four bird species in an open field habitat - Evidence of a long-distance effect. Biological Conservation 18, 299-321.

Van Rossum, F., Campos De Sousa, S., Triest, L., 2004. Genetic consequences of habitat fragmentation in an agricultural landscape on the common Primula veris, and comparison with its rare congener, P. vulgaris. Conservation Genetics 5, 231-245.

Van Wilgen, B.W., 1981. Some effects of fire frequency on fynbos plant community composition and structure at Jonkershoek, Stellenbosch. South African Forestry Journal $118,42-55$.

Wilcock, C., Neiland, R., 2002. Pollination failure in plants: Why it happens and when it matters. Trends in Plant Science 7, 270-277.

Zurita, G.A., Bellocq, M.I., 2012. Bird assemblages in anthropogenic habitats: Identifying a suitability gradient for native species in the Atlantic Forest. Biotropica 44, 412-419.

Zuur, A.F., Ieno, E.N., Walker, N.J., Savaliev, A.A., Smith, G.M., 2009. Mixed Effects Models and Extensions in Ecology with R. Springer, New York. 